\title{
A Study of the Use of Quipper School in History Learning during COVID-19 Pandemic Era
}

\author{
Tri Sastranegara (Corresponding author) \\ History Education, Graduate School, Yogyakarta State University, Indonesia \\ E-mail: tri.sastranegara.2018@student.uny.ac.id \\ Djoko Suryo \\ History Education, Graduate School, Yogyakarta State University, Indonesia \\ E-mail: djoko98@yahoo.com
}

Johan Setiawan

Graduate School, Yogyakarta State University, Indonesia

E-mail: johansetiawan767@gmail.com

Received: June 19, 2020 Accepted: July 21, 2020 Published: August 10, 2020

doi:10.5296/ijld.v10i3.17212ＵRL: https://doi.org/10.5296/ijld.v10i3.17212

\begin{abstract}
Covid-19 pandemic has brought challenges in the process of history learning in senior high schools. As a result of social distancing and work from home policies, online learning platform is needed in order to make learning process at home run well, one of which is by using Quipper School application. The use of Quipper School application is one of the solutions so that the process of history learning at home can be carried out well and efficient during the Covid-19 pandemic. This study aims to determine the use of Quipper School in history learning during the Covid-19 era. The method used in this study is analytical descriptive method through literature review. The results obtained showed that Quipper School application has a positive impact when it is used in the process of history learning at home for students who are at senior high school level. The Quipper School application offers an innovative way of learning where the teacher can manage assignments and homework more effectively so that the teacher can also recognize the strengths and weaknesses of students in capturing a given learning topic
\end{abstract}

Keywords: Quipper School, history learning, Covid-19 Pandemic 


\section{Introduction}

Coronavirus Disease (Covid-19) has spread around the world posing a serious threat to global health during the recent decades. Many countries impose policies in the form of physical distancing among citizens. The spread of Covid-19 has also caused a social change in education field which is supported by the development of information and communications technology (ICT). It changes the way we educate future generations, and there are fundamental changes in the field of education, namely: (1) the process of education throughout the world is increasingly connected, (2) redefining the role of educator, (3) broadly opening up the use of technology in supporting the implementation of learning (Breen \& Karlson, 2014; Dias, 2020; Scandurra \& Calore, 2020).

The statement above shows that Covid-19 has accelerated the transformation of education. It is shown that in a relatively short period of time traditional face-to-face learning at school is suddenly replaced by distance learning at home that relies heavily on technology including in Indonesia (Brinson, 2015: Hoskins, 2013: Seok, 2008). Educational institutions in Indonesia ranging from elementary to secondary schools have suspended face-to-face learning in order to prevent the spread of Covid-19 which becomes a major concern for many people, and this is also due to the government's policies about social distancing and work from home.

Social distancing in the context of Covid-19 is intended to prevent the spread of the diseases by maintaining physical distance between one person and another and also by reducing the activities with direct contact. Due to the existence of social restriction, all activities including works are carried out from home (WFH), where (teachers, lecturers, employees, and students) do their works at home. Work from home depends on technology, and the rise of the Covid-19 outbreak which is caused social change in the community requires the community itself, in this case teachers and students, to make significant change to do online learning at home to break the chain of the Covid-19 transmission.

Related to this issue, the Indonesian government through the Ministry of Education and Culture issued a circular letter Number 4 of 2020 regarding the implementation of education during the Covid-19 outbreak as an effort in preventing its spread in the education settings. There are three main points of the policies related to online learning, namely: (1) online learning provides meaningful experience without being burdened to complete all curriculum achievements, (2) it focuses on life skills education, (3) activities and learning tasks data are varied based on each student's interests and conditions (Ministry of Education and Culture, 2020).

In order to support policies and appeals from the ministry of education and culture, various levels of schools ranging from elementary to high schools have applied distance learning process that relies on technology such as e-learning (Hou, Chang \& Sung, 2007). Considering the data from the Central Bureau of Statictics (known as Badan Pusat Statistik in Indonesia or BPS) in 2019, regarding the use of mobile phones among students, it showed that there were about $62.52 \%$ students in cities used mobile phones while in villages were about $40.52 \%$, and nationally, students who used internet is $53.06 \%$. For that reason, e-learning which basically uses internet services is expected to be an effective solution for effective learning process 
during the Covid-19 outbreak.

E-learning is designed for online learning process where the teacher still has an important role in creating more enjoyable learning environments, and students are still able to get more information needed (McCarthy, 2015; McLean, Abry, Taylor, Gaias, 2020; VanDerHeide \& Johnson, 2020). One of the e-learning platforms that is widely used and applied today is Quipper School. Quipper as one of the edtech companies in Indonesia wants to help schools and teachers, actually school residents, in order to maximize learning activities during the threat of the Covid-19 outbreak through one of Quipper's excellent products, Quipper School (Chick, 2020; Djalante, 2010). Quipper School is a free Learning Management System (LMS) platform which offers innovative learning methods, and it is easy for both students and teachers to use.

According to the technological determinism theory proposed by Marshall McLuhan, technology will shape the way people think and act. This is proven that learning can actually be done online by using the applications such as zoom, google meeting, and Quipper School for senior high school students during the Covid-19 outbreak. The use of Quipper School in the midst of the spread of Covid-19 has become one of the solutions for online learning process. The use of Quipper School is supported by teachers and students who have been using internet services through their mobile phones or laptops. Internet services have also provided all kinds of diverse information making it easier for students to understand lessons, one of which is in learning history.

Quipper School is used by teachers to assist them managing learning materials, examinations, and students' grades (Buntoro, 2018). For students, it will be easier to do homework and online assignments in history learning through digital devices. History teachers must utilize technological sophistication to create the effectiveness of history learning during the Covid-19 outbreak (Javaid, 2010; Martín, Potocnik, \& Fras, 2017; Perbawaningsih, 2013; Rahmawati, 2015). Learning management systems have provided many benefits to teachers in the form of training (Gerwin, 2018; Hubackova, 2015; Haq, 2016; Ng, 2010).

It is expected that after the teachers use this digital application, and they apply it in the history learning process at home, it will gain a positive impact in online learning for students at home during the Covid-19 pandemic. Based on the explanation above, the problem in this study is the importance of innovative e-learning media namely Quipper School to optimize the learning process at home due to the spread of Covid-19 outbreak which requires the online learning process.

\section{Method}

The method used in this study is descriptive qualitative through literature review. Descriptive qualitative study in this context is a study to understand the phenomena occurring in the learning process during the Covid-19 outbreak, in a descriptive way which is in the form of words and language (Creswell, 2018). Descriptive study is carried out to describe the current problem solving based on reliable sources or data. Literature review can be used as a foundation or a picture of this study. The literature review is based on journal articles and the 
latest published books related to the issues which are examined in this study. The data obtained from literature review sources are then analysed using descriptive analysis method which is an analysis, where its discussion is related to existing problems with the method of grouping and summarizing the data, so that the data is informative for the reader in general (Sugiyono, 2015). Therefore, this article tries to describe each of the points in the literature review with a clear explanation and understanding based on the data which have been obtained.

\section{Result and Discussion}

\subsection{LSM (Learning Management System) as Learning Media}

The definition of e-learning is very diverse which may be different from each other, but the basic concept of e-learning according to Yatma (2016) is learning that represents the entire category of technology-based learning. While online learning or web-based learning is part of e-learning. However, along with the development of technology and the shift in content and adaptability, there is now a shift in the classical definition of e-learning into a more contemporary definition, which is a management of learning through the internet or web media which includes material aspects, evaluation, interaction, communication and collaboration.

The implementation of e-learning itself also developed including various application software and process such as computer-based learning, web-based learning, and virtual classroom. Meanwhile, online learning is part of technology-based learning that utilizes internet, intranet, and extranet resources.

Along with the rapid development of internet technology, the need for information that can be obtained quickly began to be felt as an absolute necessity rather than something exclusive. It includes the learning needs during the current Covid-19 outbreak.

After going through a series of studies and development, a more complex and complete online learning system was designed, which is called the Learning Management System (LMS). LMS is as an infrastructure that presents and manages educational content and also determines and evaluates educational objects or individuals and aims of organizational studies, including follows up on trends to increase their objectives fulfilment besides collecting and presenting data to assess the learning process of the organization as a whole.

Husaefah (2017) provides a definition of LMS as a software or web-based application technology which is used to plan, implement, and assess certain learning processes. Typically, learning management system provides instructors to create and deliver content, to monitor student participation, and to assess student performance. A learning management system (LMS) can also provide students with the ability to use interactive features such as discussion forums and video conferences.

Bailey introduces the general characteristics of LMS in education which are (1) having educational goals in relation to learning content, (2) having lesson plans that are standardized in subjects, (3) having lessons in several levels of classes that are adaptive and consistent, (4) having a management system that collects student performance results, (5) learning is presented based on the level of each student in learning, (6) having ability to combine with 
human resource systems, (7) having ability to combine content with the third-party learning device providers, (8) there is a mechanism for evaluating gaps between student competencies and managing skills and place of expertise, (9) providing and supporting evaluation compilations, (10) there are security facilities such as passwords and coding, (11) containing instruments that enable management.

Facilities such as discussion forum, chat, e-mail, learning evaluation tools, user management, and electronic material management must be available so that users are able to learn in a learning environment which is not far different from the real classroom atmosphere. In this system, teachers are no longer active in giving material or asking students to ask questions about something that they do not understand, but students are trained to learn critically and actively.

\subsection{Quipper School Application as an Online Leraning Management System}

Quipper School is one of the products of Quipper company in the form of Learning Management System which provides a platform to give online assignments and to access materials and also some related questions which are based on the 2013 curriculum for free during Covid-19 pandemic. Therefore, through Quipper School, teachers can provide their students the online assignments which can be accessed through students' mobile devices (smartphones, tablets and netbooks), and they can also monitor their learning progress online. Students can learn wherever they want as long as their devices are connected to the internet.

Quipper School has several important features in supporting the online history learning process during the Covid-19 era. To use the Quipper School application, history teachers may start by: (1) logging in using a facebook account or through manual registration, (2) creating a class with a maximum of 60 students, (3) creating a new class, then in Quipper School will give you a unique "class code". The teachers then can copy and send it to students. Furthermore, students register and enter the class by using the access code provided by the teacher, (4) after that, both teachers and students are connected via an access code in the classroom.

Quipper School has several important features, including: (1) Quipper School Link; this feature is provided for teachers to create and manage classes online. This feature can be used by teachers who aim to provide homework, practice, and even examination for students. This school link system provides learning materials and questions consisting of various topics for each subject, including history subjects, for the seventh grade students at junior high school to the twelfth grade students at senior high school (science and social studies). In addition, there are instrument facilities that can be used by the teacher to perform analysis functions, formative evaluation and summative evaluation such as: (a) monitoring students in learning activities (student score reports on their assignment/homework), (b) viewing data analysis/graphs of student development, (c) observing the analysis of topics that students have or have not mastered yet, (d) sending messages or responses to students' questions, (e) making announcements for students, and (f) printing the student score reports.

(2) Quipper School Learn; this feature is intended for students where they have facilities to access all topics, to read subjects and to work on questions given by the teacher. The features in 
Quipper school learn consist of: (a) profile, to see learning statistical data, (b) to do list, to access all of the assignments, (c) class, to see class information or to join in other classes, (d) try again, to try the topics that they have not mastered yet, (e) messages, to send messages to the teacher, and (f) notifications, to see all announcements that have been made by the teacher.

\subsection{The Use of Quipper School in History Learning during the Covid-19}

The integration of technology in learning is identified to improve students learning outcomes. Technology-based learning will be effective if the role of the history teacher in history learning is as a facilitator or makes it easy for students to learn (VanSledright, 2011; Virgin, 2014). Technology integration in the process of history learning will make the learning more effective (Gaudin \& Chalies, 2015; Green, Green \& Pensiero, 2015; Guo, Saab, Post \& Admiral, 2020; Hokka \& Etelapelto, 2014; Jerrim \& Macmillan, 2015; Levy \& Petrulis, 2012; Martell, 2013a; Martell, 2013b).

It can be said that effective learning is learning that optimally integrates information and communications technology (Martinelle, 2020). One of the uses of information and communications technology in history learning is to use e-learning (Crosling, Nair \& Vaithilingam, 2015; Endacott, \& Sturtz, 2015; Fung, 2017).

The Covid-19 outbreak requires distance learning so that it is not done face-to-face (Burkhauser, 2017; Nicola, 2020). This is due to social distancing and work from home policies. In the modern era, all human activities become easier by the help of technology, and now learning can be done at home through the Quipper School learning application. Quipper School is a solution to present e-learning based history learning or commonly referred to as online learning model.

The advantages of the Quipper School application include: (1) making student learning activities not limited to space and time, they can learn whenever and wherever they want, (2) using Quipper School in student learning activities makes it more relaxed, students can use their mobile phones or laptops to do the assignments given by their history teachers, and (3) learning becomes effective (Biasutti, \& EL-Deghaidy, 2015; Stambouugh, 2020).

Difficulties in using Quipper School are: (1) Teachers and students must have good internet access, and (2) teachers and students must be able to operate Quipper School well. Of course, to overcome these problems, history teachers must learn first, so here the school plays an active role in providing training on e-learning based learning to teachers in their schools.

The benefits obtained by the teacher in using Quipper School in the history learning process during the Covid-19 era include:

\subsubsection{Interaction Forum for History Teachers and their Students}

Quipper School can be accessed through devices such as mobile phones or laptops connected to the internet through therefore students and history teachers can access Quipper School anywhere and anytime. It can be accessed through a WiFi connection or an internet quota package at home, and this shows that students and history teachers are able to be connected in virtual classes anywhere easily during the Covid-19 outbreak that is happening now in 
Indonesia.

Students and history teachers are also connected through other social media such as twitter and facebook, so the platform provides a useful experience in using technology in the lives of students at home. The necessity of teachers and students in using technology for learning makes learning experiences more enjoyable according to various conditions of students. For history teachers themselves, with the assistance of communication through social media among students, at least they can notice that students spend more of their time online to study history rather than to do things that are less useful for the history learning process.

\subsubsection{The Use of Learning Materials and Contents}

After the history teachers are able to master the online learning on Quipper School, another task of them is to use the materials which consist of various topics of school subjects for students from grade VII of junior high school to grade XII of senior high school (both science and social studies), including history subjects. The challenge for teachers is how they can use various learning methods and models in online learning. For example, the teacher can create a creative video content as teaching material. It makes a history teacher be more persuasive because it can attract students more in learning history materials (Belagra \& Draoui, 2018; Oattes, Oostdam, de Graaff, \& Wilschut, 2018; Post, Guo, Saab, \& Admiraal, 2019). Therefore, by applying the Quipper School learning model at home, students may not feel bored in following history learning which is in the form of e-learning.

\subsubsection{Learning Evaluation}

Learning evaluation is done by assessing student activities in completing history assignments, supported by both classic and individual message and announcement features, it will be easier for students to communicate with their teacher whenever they want. The use of the Quipper School application for students in completing their assignments can lead to creativity in developing their knowledge. Various learning methods from history teachers can create a creative learning product that can develop students thinking through their own analysis in completing their assignments (Brew \& Saunders, 2020; Brown, 2013; Dallinger, Jonkman, Holmm \& Fiege, 2016; Fogo, 2014). The assessment given by the history teacher becomes more transparent and accountable which means that all students can find out how much the score they obtain. Thus, they are certain that their teacher is objective in providing an assessment.

\section{Conclusion}

Quipper School learning application is a free online-based application that can be used by history teachers in the learning process during the COVID-19 outbreak due to policies of social distancing and work from home. Quipper School is the right solution to be used by history teachers because it is an effective and interactive learning media. The learning goals are able to be reached optimally because it assists students to comprehend the history materials. Quipper School becomes one of the solutions for passive learning in order to increase student motivation. Quipper School is useful in providing appreciation and inspiration in order to increase student and teacher comprehension which can be done from home. Based on the 
findings of the literature review, it can be concluded that the use of Quipper School application in history learning at home is effective to help students comprehend the learning materials

\section{References}

Belagra, M., \& Draoui, B. (2018). Project-based learning and information and communication technology's integration: Impacts on motivation. International Journal of Electrical Engineering Education, 293-312. https://doi.org/10.1177/0020720918773051

Biasutti, M., \& EL-Deghaidy, H. (2015). Interdisciplinary project-based learning: An online wiki experience in teacher education. Technology, Pedagogy and Education, 24(3), 339-355. 10.1080/1475939X.2014.899510

Buntoro, G. S., Ariyadi, D., \& Astuti, I. P. (2018). Pemanfaatan E-Learning Quipper School oleh guru dan siswa untuk Optimalisasi Pembelajaran di SMA N. 1 Ponorogo. Jurnal pengabdian kepada masyarakat, 3(2), 157-167. https://doi.org/10.22146/jpkm.27404

BPS. (2019) Potret Pendidikan Statistik Pendidikan Indonesia 2019. Jakarta: Badan Pusat Statistik.

Breen, R., \& Karlson, K. B. (2014). Education and social mobility: New analytical approaches. European Sociological Review, 30(1), 107-118. https://doi.org/10.1093/esr/jct025

Brew, A. \& Saunders, C. (2020). Making sense of research-based learning in teacher education, Teaching and Teacher Education, 87, 1-11. 10.1016/j.tate.2019.102935

Brinson, J. R. (2015). Learning outcome achievement in non-traditional (virtual and remote) versus traditional (hands-on) laboratories: A review of the empirical research. Computers \& Education, 87, 218-237. https://doi.org/10.1016/j.compedu.2015.07.003

Brown, P. (2013). Education, opportunity and the prospects for social mobility. British Journal of Sociology of Education, 34(6), 678-700. https://doi.org/10.1080/01425692.2013.816036

Burkhauser, S. (2017). How much do school principals matter when it comes to teacher working conditions?. Educational Evaluation and Policy Analysis, 39(1), 126-145. https://doi.org/10.3102/0162373716668028

Chick, R. C., et.al. (2020). Using Technology to Maintain the Education of Residents During the COVID-19 Pandemic. Journal of Surgical Education, 1-4. https://doi.org/10.1016/j.jsurg.2020.03.018

Crosling, G., Nair, M., \& Vaithilingam, S. (2015). A creative learning ecosystem, quality of education and innovative capacity: A perspective from higher education. Studies in Higher Education, 40 (7), 1147-1163. https://doi.org/10.1016/j.jsurg.2020.03.018

Dallinger, S., Jonkman, K., Holmm, J., \& Fiege, C. (2016). The effect of content and language integrated learning on students' English and history competences. Killing two birds with one stone? Learning and Instruction, 41, 23-31. 
https://doi.org/10.1016/j.learninstruc.2015.09.003

Dias, M., \& Lopes, R. D. O. A. L. (2020). Will the Covid-19 Pandemic Reshape Our Society. EAS Journal of Humanities and Cultural Studies, 2(2), 81-85. 10.13140/RG.2.2.26297.93288

Djalante, R., et.al. (2010). Review and analysis of current responses to COVID-19 in Indonesia: Period of January to march 2020. Progress in Disaster Science, 6, 1-9. https://doi.org/10.1016/j.pdisas.2020.100091

Endacott, J. L., \& Sturtz, J. (2015). Historical empathy and pedagogical reasoning. Journal of Social Studies Research, 39 (1), 1-16. https://doi.org/10.1016/j.jssr.2014.05.003

Fogo, B. (2014). Core practices for teaching history: The results of a Delphi panel survey. Theory \& Research in Social Education, 42(2), 151-196. 10.1080/00933104.2014.902781

Fung, D. (2017). A connected curriculum for higher education. London: UCL Press.

Gaudin, C., \& Chalies, S. (2015). Video viewing in teacher education and professional development: A literature review. Educational Research Review, 16, 41-67. 10.1016/j.edurev.2015.06.001

Gerwin, R. L. Kaliebe, K., \& Daigle, M. (2018). The Interplay Between Digital Media Use and Development. Child Adolesc Psychiatric Clin $N$ Am, 345-355.: 10.1016/j.chc.2017.11.002.

Green, A., Green, F., \& Pensiero, N. (2015). Cross-country variation in adult skills inequality: Why are skill levels and opportunities so unequal in anglophone countries? Comparative Education Review, 59(4), 595-618. https://www.jstor.org/stable/10.1086/683101?seq=1\#metadata_info_tab_contents

Guo, P., Saab, N., Post, L. S., \& Admiral, W. (2020). A Review of project-based learning in higher education: Student outcomes and measures. International journal of Educational Research, 102, 1-13. https://doi.org/10.1016/j.ijer.2020.101586

Haq, U.A. Magoulas, G. Jamal, A. Majeed, A., \& Sloan, D. (2016). Users Perseption of E-Learning Environtments and Service Effectiveness. Journal of Enterprise Information Management, 111, 1-25. https://eprints.bbk.ac.uk/18983/1/JEIM-PDF_Proof.pdf

Hokka, P., \& Etelapelto, A. (2014). Seeking new perspectives on the development of teacher education: A study of the Finnish context. Journal of Teacher Education, 65(1), 39-52. https://doi.org/10.1177/0022487113504220

Hoskins, B. J. (2013). Is Distance Learning Transformational?. The Journal of Continuing Higher Education, 61(1), 62-63. 10.1080/07377363.2013.759488

Hubackova, S., \& Ruzickova, S. (2015). ICT In Lifelong Education. Social and Behavioral Sciences, 186, 522-525. 10.1016/j.sbspro.2015.04.176

Hou, H.-T., Chang, K.-E., \& Sung, Y.-T. (2007). An analysis of peer assessment online discussions within a course that uses project-based learning. Interactive Learning 
Environments, 15(3), 237-251. 10.1080/10494820701206974

Husaefah, H., \& Marhiah. (2017). Application of E-Learning quipper school. Internasional Journal of Social Science and Humanities Research, 5, 522-526. https://www.researchpublish.com/download.php?file=Application\%20of\%20E-Learning\%20 Quipper\%20School-4955.pdf\&act=book

Javaid, M. et al. (2020). Industry 4.0 technologies and their applications in fighting COVID-19 pandemic. Diabetes \& Metabolic Syndrome: Clinical Research and Review, 20, 1-12. 10.1016/j.dsx.2020.04.032

Jerrim, J., \& Macmillan, L. (2015). Income inequality, intergenerational mobility, and the great gatsby curve: Is education the key? Social Forces, 94(2), 505-533. https://doi.org/10.1093/sf/sov075

Kementerian Pendidikan dan Kebudayaan. Surat Edaran Kemdikbud No 4 Tahun 2020 mengenai Pelaksanaan Pendidikan Dalam Masa Darurat Coronavirus Disease (Covid-19). Jakarta: Kemendikbud.

Levy, P., \& Petrulis, R. (2012). How do first-year university students experience inquiry and research, and what are the implications for the practice of inquiry based learning? Studies in Higher Education, 37(1), 85-101. https://doi.org/10.1080/03075079.2010.499166

Martell, C. C. (2013a). Learning to teach history as interpretation: A longitudinal study of beginning teachers. Journal of Social Studies Research, 37(1), 17-31. https://doi.org/10.1016/j.jssr.2012.12.001

Martell, C. C. (2013b). Race and histories: Examining culturally relevant teaching in the US history classroom. Theory \& Research in Social Education, 4l(1), 65-88. https://doi.org/10.1080/00933104.2013.755745

Martinelle, R. (2020). Using video-stimulated recall to understand the reflections of ambitious social studies teachers. The Journal of Social Studies Research. 1-6. ttps://doi.org/10.1016/j.jssr.2020.03.001

Martín, P., Potocnik, K., \& Fras, A. B. (2017). Determinants of students' innovation in higher education. Studies in Higher Education, 42(7), 1229-1243. https://doi.org/10.1080/03075079.2015.1087993

McCarthy, G. (2015). Motivating and enabling adult learners to develop research skills. Australian Journal of Adult Learning, 55, 307-328. https://www.semanticscholar.org/paper/Motivating-and-Enabling-Adult-Learners-to-Develop -McCarthy/63d75ea13af22d5cdd33604fe0722af34e690114

McLean, L., Abry, T., Taylor, M., \& Gaias, L. (2020). The influence of adverse classroom and school experiences on first year teachers' mental helth and carees optimism. Teaching and Teacher Education, 87, 1-13. 10.1016/j.tate.2019.102956

Ng, Y. M., \& Peggy, P. L. (2020). Coronavirus disease (COVID-19) prevention: Virtual Ming 
classroom education for hand hygiene. Nurse Education in Practice, 20, 1-8. https://doi.org/10.1016/j.nepr.2020.102782

Nicola, M., et al. (2020). Evidence Based Management Guideline for the COVID-19 Pandemic. International journal of Surgery, 20, 1-17. 10.1016/j.ijsu.2020.04.001

Oattes, H., Oostdam, R., de Graaff, R., \& Wilschut, A. (2018). The challenge of balancing content and language: Perceptions of Dutch bilingual education history teachers. Teaching and Teacher Education, 70, 165-174. https://doi.org/10.1016/j.tate.2017.11.022

Perbawaningsih, Y. (2013). Plus minus of ICT Usage In Higher Education Student. Social and Behavioral Sciences, 103, 717-724. 10.1016/j.sbspro.2013.10.392

Post, L. S., Guo, P., Saab, N., \& Admiraal, W. (2019). Effects of remote labs on cognitive, behavioral, and affective learning outcomes in higher education. Computers \& Education, 140, 103-116. https://doi.org/10.1016/j.compedu.2019.103596

Rahmawati, R., Sudiyanto, \& Sumaryati, S. (2015). Keefektifan Penerapan E-Learning-quipper school Pada Pembelajaran Akuntansi di SMA Negeri 2 Surakarta. Jurnal Tata Arta UNS, 1, 1-12. https://docplayer.info/32194527-Keefektifan-penerapan-e-learning-quipper-school-pada-pem belajaran-akuntansi-di-sma-negeri-2-surakarta.html

Scandurra, R., \& Calore, J. (2020). How adult skills are configured. International journal of educational Research, 99, 1-14. https://doi.org/10.1016/j.ijer.2019.06.004

Seok, S. (2008). The aspect of e-learning. International Journal on E-Learning, Proquest, 7(4), 725-741. 10.20961/shes.v1i2.26756

Stambough, J. B., et al. (2020). The Past, Present, and Future of Orthopaedic Education: Lessons Learned from the COVID-19 Pandemic. The Jurnal of Arthroplasty, 20, 1-17. 10.1016/j.arth.2020.04.032

VanDerHeide, J., \& Johnson, A. (2020). Examining preservice teachers' narratives of teaching dialogically. Teaching and Teacher Education, 87, 1-11. 10.1016/j.tate.2019.102946

VanSledright, B. A. (2011). The challenge of rethinking history education: On practices, theories, and policy. New York: Routledge.

Virgin, R. (2014). Connecting learning: How revisiting big idea questions can help in history classrooms. The Social Studies, 105(4), 201-212. https://doi.org/10.1080/00377996.2014.917065

Creswell, J. (2018). Penelitian Kualitatif dan Desain Riset Memilih di Antara Lima Pendekatan (Edisi ke-3). Yogyakarta: Pustaka Pelajar.

Sugiyono. (2015). Metode Penelitian Kuantitatif, Kualitatif dan R\&D. Bandung: Afabeta

Yajma, K., Hayakawa, Y., Kashiwaba, Y., Takahshi, A., \& Oiguchi, S. (2016). Construction of Active Learning Environtment by The Student Project. Procedia Computer Sceinces, 96, 


\section{Macrothink}

1489-1496. https://doi.org/10.1016/j.procs.2016.08.195

\section{Copyright Disclaimer}

Copyright for this article is retained by the author(s), with first publication rights granted to the journal.

This is an open-access article distributed under the terms and conditions of the Creative Commons Attribution license (http://creativecommons.org/licenses/by/4.0/). 